\title{
THEORY OF THE SEPARATION OF POWERS IN THE WORKS OF CHARLES MONTESQUIEU
} ТЕОРІЯ ПОДІЛУ ВЛАД У ПРАЦЯХ ШАРЛЯ МОНТЕСК'Є

This article is about the theory of the separation of powers and the system of checks and balances based on the analysis of works of Charles Montesquieu. The article elucidates various discussions by the philosopher and how they contributed to his model of democratic government. The article begins with the underlying discussion of the role of natural and political law in the statebuilding process and how social contract stimulated the appearance of government. It touches upon liberty describing the role of individuals in society and the connection between the law and liberty. Later, the article includes an extensive discussion of the forms of government defined by Montesquieu, their underlying principles, and how they influence social hierarchy. Democracy, aristocracy, monarchy, and despotism are discussed separately; however, the article emphasizes ties between them to allow better differentiation and provides tools for the identification of transforming governments. Specific attention is devoted to the organization of government and the separation of powers or its absence in it. After a general overview of the forms of government, the article focuses on democracy and proceeds to elucidate the structure that Montesquieu considers essential for the survival of democracy. It encompasses the separation of powers, mechanisms of checks and balances, and their peculiarities. The article provides an in-depth overview of each branch of authority and its connections to others. The purpose of such structure is to identify elements that are often overlooked but remain significant. Its relevance is determined by the latest global developments in democracies. The model proposed by the author can be used to identify issues in democracies that suffer from individual desire to concentrate authority in one hands. Strong institutions al system and effective mechanism of checks and balances are strong factors in prevention of corruptization of government. Consequently, Montesquieu's theory of the separation of powers can be considered as one of the keys for the improvement of existing structures of government.

Key words: separation of powers, checks and balances, state, government, rule of law.
Стаття присвячена теорії поділу влади та системі стримувань і противаг на основі аналізу робіт Шарля Монтеск'є. У статmі висвітлюються різні дискусії фрілософра та їхнє значення для моделі демократичного правління. Стаття розпочинається із грунтовного обговорення ролі природного та політичного права в державотворчому процесі та того, як суспільний договір стимулював появу уряду. Стаття зачіпає визначення свободи, описує роль індивідів у суспільстві та зв'язок між законом і свободою. Також наведене обширне обговорення форм правління, визначених Ш. Монтеск'є, їхніх основних принципів і того, як вони впливають на соиіальну ієрархію. Окремо обговорюються демократія, аристократія, монархія та деспотія; проте у статті підкреслені зв'язки між ними, щоб забезпечити кращу диференціацію та висвітлити інструменти для ідентифрікації урядів, що перебувають у процесі трансформації. Особлива увага приділяється організації влади та розподілу влади або його відсутності. Після загального огляду форм правління зосереджено увагу на демократії, з'ясовано, яку структуру Ш. Монтеск'є уважав важливою для виживання демократії. Стаття охоплює принципи поділу влад, механізми стримувань і противаг, їхні особливості. У статmі надано глибокий огляд кожної гілки влади таїзв'язківз іншими. Метою такої структури є визначення елементів, які часто не помічаються, але залишаються значущими. Актуальність статmі визначається останніми глобальними подіями в демократичних країнах. Запропонована автором модель може бути використана для визначення проблем у демократичних країнах, які страждають від індивідуального бажання зосередити владу в одних руках. Сильна інституиійна системай ефективний механізм стримувань іпротиваг є основними чинниками запобігання корумпованості влади. Отже, теорію поділу влади Ш. Монтеск'є можна вважати одним із ключів до вдосконалення наявних структур влади.

Ключові слова: поділ влади, система стримувань і противаг, держава, уряд, верховенство права.
The separation of powers is crucial for democracy because it ensures the independence of the branches of authority and the impartiality of the decision-making process in government. Each state has its peculiarities in the division of responsibilities that often lead to conflicts because each branch tries to maximize its influence on the system; therefore, returning to the theory is crucial for a deeper understanding of the issue and seeing how to maximize the effectiveness of government through the improvement of the separation of powers.
Available research. Charles Montesquieu is one of the most prominent philosophers who worked on the topic of government; therefore, he receives much attention from academics from different fields. The list of some of the researchers who worked on the topic includes $\mathrm{S}$. Krause, D. Bigo, J.-P. Andrieux, A. de Dijn, A. Radasanu, D. Bates, I. Berlin, P. Manent.

Novelty. Montesquieu and his ideas are frequently discussed from the philosophical perspective. The theory of the separation of powers is also often viewed as a core of 
democracy by political scientists. However, the article focuses on the description of the model for its future comparison with real-life cases to improve the quality of public administration.

Present-day relevance. Today, the tendency to accumulate power and disable some of the mechanisms of checks and balances is evident in democratic countries. Present cases include exercising authority over all three branches or making the judiciary political to serve the interests of ruling politicians rather than the law. Such a tendency is detrimental to democracies themselves and the world order; therefore, this issue requires additional study from a theoretical point of view in order to prevent or resolve it.

Objective. The objective of the article is to describe a model of the separation of powers and mechanisms of checks and balances as proposed by Charles Montesquieu for the further use in comparative analysis.

The idea of the separation of powers dates back to Ancient Greece and was discussed by a number of philosophers over time; however, Charles Montesquieu grasped this idea and transformed it into a theory. One can argue that John Locke also contributed to the theory of the separation of powers. He considered the structure of government from the perspective of how well it fits the needs of society, contrary to the institutional focus of Montesquieu; thus, Locke developed the theory of modern constitutionalism $[11$, p. 4$]$ while Montesquieu was the one to focus on the separation of powers.

As Montesquieu was not the first one to emphasize the importance of the topic, he was heavily influenced by the arguments of Aristotle and Polybius [12, p. 28]. Besides, philosophical debates of the 16 th century and social tensions linked to absolutism contributed to the search for alternatives in which broad masses formally obtain permission to participate in political and state affairs. The theory of the separation of powers arose as a result of political and ideological pluralism and a need to give representatives of different groups of thought access to their self-expression [5, p. 185]. Such pluralism had to be accommodated in government and stimulated demand for a new structure; thus, the theory of the separation of powers satisfied this demand and provided a new model for state-building.

However, one should not underestimate the impact of Locke's philosophy on Montesquieu. Montesquieu also considered society and its structure as a crucial element of state-building because he recognized that the political law should be based on and remain coherent with the natural law [9, p. 24]; therefore, he also devoted attention to the social contract. This conception of society came from the notion that individuals have liberty, they are seen as free agents. Montesquieu's definition of liberty is closely related to the social contract because he claimed that people cannot be free when they do not feel safe. Freedom itself does not imply the no-harm principle while foreseeing that individuals can harm others or expect someone to do it to them; thus, liberty includes a set of laws that protect people from harm and ensure their safety $[1$, p. 717]. The philosopher starts his discussion by saying that individuals should be free to act as they please, but within a defined legal framework to secure their well-being.

Montesquieu believed that the main task of the government is to provide individuals with liberty and to maximize it as much as possible. In other words, the government is responsible for creating a framework and rules for human interaction. On the other hand, a desire to maximize authority is inherent in human nature while the power itself corrupts [7, p. 243]. Consequently, in such a society, representatives of the government would be above other citizens while they would strive to gather authority in their hands. From this perspective, Montesquieu stated that "it is necessary from the very nature of things that power should be a check to power" [9, p. 112]; that is why he claimed that every power should be counterbalanced through the system of checks and balances that is essential for a society that wishes to protect individual liberty.

According to Montesquieu, laws are the most important component of state-building because their quality determines the future of a state. The philosopher believes that the system of laws establishes a certain social order through the system of checks and balances included in these laws [2, p. 440]. Consequently, they cannot be interpreted separately as being just an element of the whole picture. From another perspective, an alteration to a law that imposes some checks and balances can have a destructive effect on the entire system. Therefore, states should aspire to secure this legal stability to ensure their survival.

As the main function of the laws is to secure the stability of a state, they also prevent reforms from taking place. Montesquieu thinks that reforms beginning with a change of one law are destructive to a state because they interfere with its equilibrium. On the contrary, reforms should logically follow from the analysis of the entire system [2, p. 245]. They should complement and improve it; therefore, reforms should be structural, in so far as they address structural issues rather than separate elements of the system. 
Even though a state should aspire to its stability, it might not be possible due to the constant influence of external factors. Montesquieu claimed that small changes to the system had a significant impact on it because they stimulated discussion. Different opinions contributed to diversity in the approach that looked for answers within and outside the system [3, p. 137]. Consequently, the discussion led to further study of the existing structure and identification of its gaps. Diversity resulted in improvements and contributed to the survival of the system by increasing its universality.

Montesquieu agrees state structures can differ and contributes to the discussion about the forms of government with his classification. The philosopher identifies three types: republican, monarchic, and despotic [9, p. 32]. The republican government can take two forms: democratic and aristocratic. He argues that changes to the law can lead to a transformation of the government in both directions. Besides, each form has an underlying principle that can be corrupted or misplaced. This principle regulates relationships between members of society and has specific implications for the social hierarchy [9, p. 32]. Thus, a state's structure is not constant due to the impact of its environment.

Montesquieu believes that one should consider the rights of the most disadvantaged individuals to determine the type of government $[9$, p. 26]. A despotic government is the only one that destroys a state according to Montesquieu because a despot is not bound by the law. The whole society lives to satisfy each whim of one person; thus, this person has unlimited authority to change the law. Moreover, despots acquire the power to decide on the lives of other members of society. A despot becomes a synonym to the law while individuals do not know the law and by that cannot protect themselves; thus, they lose all their rights. In a despotic government, there is no space for other people's opinions; therefore, its underlying principle is fear [9, p. 36].

The only difference between monarchy and despotism is that a monarch possesses an authority that is bounded by the law. This notion is true of constitutional monarchies, but not of absolute monarchies, which are despotic. The authority in a monarchic government can be limited; thus, people can be more confident in their future in comparison to a despotic government. Besides, it has a unified center of decision-making that results in high-speed decision-making, but power is defined by the constitution that can prevent abuse. The underlying principle is the honor of a monarch $[9$, p. 35]; that is why honor determines where a state will turn into a flourishing monarchy or fall into despotism.

According to the philosopher, a republic is the form of government that is the most difficult to control. It requires constant equilibrium between equality and frugality. Equality is essential to enforce the law in a state while frugality stimulates individuals to work and improve their social standing, in other words, to contribute to society $[9$, p. 46$]$. In a republic, the underlying principle is a virtue because its lack determines the probability of the corruptness of people in government $[9, p .32]$. In addition, if some individuals violate the law, others can start considering obedience to the law as a violation of their freedom. Consequently, equality is the basis of society in a republic.

In a democracy, individuals take personal responsibility for the survival of a state and participate in decision-making; thus, a democratic society consists of citizens. They also join public service due to feeling trusted; thus, they take even more responsibility and sacrifice themselves for the general benefit. Every citizen can run for public office or apply for a position in the government [8, p. 379]; however, this is not the only opportunity. A state can offer either voluntary or compulsory military service with the possibility to stay on a contract basis to protect their country. Thus, a shared feature of citizens is their willingness to prioritize a state over their personal interests.

Aristocracy also requires virtue to survive; however, due to the special status of nobility in society, virtue's role is diminished. Nobility possesses the power to control other people's lives; thus, moderation prevails over virtue [9, p. 34]. Also, in an aristocracy, the understanding of equality differs from democracy through the division into two classes: nobility and other citizens; thus, one evaluates equality only in relation to the representatives of own class. Therefore, aristocracy depends on the decisions of the nobility and their willingness to moderate.

Unlike other philosophers, Montesquieu did not identify an ideal government by its form. He claimed that the organizational structure is far more important. Montesquieu took the model proposed by Locke as a basis for his theory; therefore, in his view, the government should be divided into three branches of authority: the legislative, the executive, and the judiciary $[10$, p. 9]. The contribution of Montesquieu was the addition of new mechanisms of checks and balances through a clear definition of the responsibilities of each branch. Moreover, he emphasized the role of the judiciary and developed its structure in an original way. 
Montesquieu defines the legislature as dependent on human law and the executive on civil law. According to him, the legislature is responsible for making permanent or temporary laws while the executive decides on war and peace, stability, and relationships with other states. The judiciary covers judging and punishing crimes. Montesquieu later calls the executive a "power of execution" and the "executing" a "power of judging" [9, p. 112]. Therefore, following the example of England, he introduces a modern vision of the branches of authority and their functions.

Montesquieu is convinced that there will be no liberty in society if the branches are not separate. Moreover, he describes various cases of shared responsibilities to prove that such an idea would destroy the system because of internal influences. The legislative power, in his view, should be comprised of people's representatives based on their place of living. These representatives should engage in discussions with people and become the "voice of the nation" [9, p. 175]. All individuals living in a specific district should have a voting right to choose their representative for some period of time. The legislature should fulfill its functions through the assemblies while the executive should ensure that these assemblies take place according to the rules; therefore, the role of the executive is connected to organizational responsibilities.

One of the distinctive differences between Locke's and Montesquieu's theories lies in the role of the judiciary. Montesquieu believes that the judiciary is a critical element in checking and balancing that should be fully independent of the other two. He advocated for judges to be elected by society to limit their connections to the representatives of the legislative and the executive. In his opinion, judging is essential for any type of government to support the existing order; however, judging as a process differs through the role of law. In a democracy, a constitution was used as a source of any judgment while, in a monarchy, judges could rely on personal opinion when an issue was not covered by the law [9, p. 65]. Besides, the process of judgment involves discussion of opinions, in a monarchy, and individual choice of options ("guilty", "not guilty", "abstention") with the later calculation of the majority, in a republic. The philosopher emphasized that the quality of judgment determines the stability of a government.

Nevertheless, judges could also be influenced by others. Montesquieu considered corruption as a huge threat to the proper functioning of government. In a democracy, it appeared due to the desire for equality. Citizens wished to become equal to those governing them and, when they succeeded, spread their influence over three branches of authority. In this case, citizens stopped respecting the legislature and disregarded the decrees of the executive [9, p. 87]. In an aristocracy, the level of corruption increased with the number of nobility who ruled. Their lack of assurance in the future led to the usurpation of power and created a closed circle of those who stand above the rest [9, p. 89]. Corrupted monarchy began its transformation into tyranny. Corruption got to the core of governments - their principle; therefore, Montesquieu considered it a ruinous factor that stimulated the shift of governments to other forms; as a rule, to less democratic ones.

Montesquieu emphasized that governments are not stable and may shift from one form to another; therefore, even though the independence of branches of authority was crucial for the proper fulfillment of their responsibilities, they need to cooperate to stabilize a state. The legislative, the executive, and the judiciary are interconnected to secure the well-being of citizens while not being able to act separately [6, p. 182]. Such structure poses challenges for public administration because it requires efficient organization of hierarchy, the ability of the hierarchy to enforce mechanisms of checks and balances and avoid disputes connected to division of responsibilities.

The theory of the separation of powers remains significant and highly applicable in public administration due to its contribution to the organization of the government vertical. However, one of its shortcomings is that Montesquieu tries to envisage an ideal society in the process of its development. He speaks about the possibility of corruption, but on a small scare; thus, it occurs on an individual basis, but does not become a structural element of a government. Montesquieu states that it is in the nature of people to desire to accumulate power. Public servants are no exception while the motivation of individuals to start a career in the branches of authority can come not only from feeling responsible citizens and wishing to sacrifice themselves for their state [8, p. 390].

Montesquieu develops his model of a government based on the underlying principle in society; however, he himself states that these principles are not constant and can shift over time. That is why one should focus on the structural contribution of the theory rather than the philosopher's idea that institutions are a product of society [4, p. 190]. The structure of a government and mechanisms of checks and balances should preserve the political system of a state from volatility and act as safeguards of democracy. Consequently, society and institutions remain in 
constant interaction and causality relationship for a democratic state to survive.

Conclusions. Charles Montesquieu is one of the most-appraised philosophers when talking about government. His theory of the separation of power is not original because it encompasses thoughts and ideas of other philosophers dating back to Ancient Greece. Nevertheless, the contribution of Montesquieu is in gathering available information of the topic, its systematization, and elaboration to fill in the gaps or provide clarifications.

Montesquieu discusses the typology of the forms of government and their peculiarities; however, even though he recognizes the changing nature of a state, he claims that its survival can be ensured through the structure of government. According to the philosopher, democracy is an ideal form of government because it provides maximal liberty for its citizens while ensuring respect for the rule of law. He identified three branches of authority: the legislative, the executive, and the judiciary and defined their functions in a way that they can exercise control over each other. Montesquieu devotes additional attention to the system of checks and balances; consequently, he produces a model that can be used for evaluation of real-life government model that is the opportunity for future research.

\section{REFERENCES:}

1. Montesquieu C. Montesquieu on the Effect of Laws on Population. Population and Development Review. 1991. Vol. 17. № 4. P. 717-29. DOI: 10.2307/1973604

2. Andrieux J.-P. Actualités de Montesquieu Notes de Lecture. Revue Historique de Droit Français et
Étranger (1922). 2016. Vol. 94. № 3. P. 439-446. URL: http://www.jstor.org/stable/26386071

3. Bates D. Systems of Sovereignty in Montesquieu. States of War: Enlightenment Origins of the Political. Columbia University Press, 2012. P. 134-170. URL: http://www.jstor.org/stable/10.7312/bate15804.9

4. Montesquieu / I. Berlinet et al. Against the Current: Essays in the History of Ideas / edited by H. Hardy. Princeton University Press, 2013. P. 164-203. URL: http://www.jstor.org/stable/j.ctt2tt8pw.13

5. Bigo D. Quand Montesquieu Se Transnationalise. Cultures et Conflits. L'Harmattan, 2011. № № 81/82, P. 183-91. URL: http://www.jstor.org/stable/23703546

6. de Dijn A. On Political Liberty: Montesquieu's Missing Manuscript. Political Theory. Sage Publications, Inc., 2011. Vol. 39. № 2. P. 181-204. URL: http://www.jstor.org/stable/23036087

7. Krause S. History and the Human Soul in Montesquieu. History of Political Thought. Imprint Academic Ltd., 2003. Vol. 24. № 2. P. 235-61. URL: http://www.jstor.org/stable/26219958

8. Manent P. Montesquieu and the Modern Experience. Government and Opposition. Cambridge University Press, 1994. Vol. 29. № 3. P. 378-391. URL: http://www.jstor.org/stable/44483861

9. Montesquieu C., Nugent T., Alembert J. The Spirit of Laws. New York : Colonial Press, 1899.

10. Radasanu A. Montesquieu on Ancient Greek Foreign Relations: Toward National Self-Interest and International Peace. Political Research Quarterly. 2013. Vol. 66. № 1. P. 3-17. URL: http://www.jstor.org/ stable/23563585

11. Rhonheimer M. St. Thomas Aquinas and the Idea of Limited Government. Journal of Markets and Morality. 2019. Vol. 22. № 2. URL: https://www. marketsandmorality.com/index.php/ mandm/article/view/1443

12. Shackleton R. Montesquieu, Bolingbroke, and the Separation of Powers. French Studies. January 1949. Vol. 3. № 1. P. 25-38. 